\title{
PENGARUH EKSTRAK KULIT BUAH NAGA MERAH (HYLOCEREUS POLYRHIZUS) TERHADAP OVARIUM MENCIT MODEL ENDOMETRIOSIS
}

\author{
Sagita Candra Puspitasari ${ }^{1}$, Hendy Hendarto ${ }^{2}$, Widjiati ${ }^{3}$ \\ ${ }^{1}$ Mahasiswa Magister IImu Kesehatan Reproduksi, Fakultas Kedokteran, \\ Universitas Airlangga Surabaya, Email : frice_star89@yahoo.co.id \\ 2 Departemen Obstetri dan Ginekologi, Fakultas Kedokteran, Universitas \\ Airlangga, RSUD Dr. Soetomo \\ ${ }^{3}$ Departemen Embriologi Veteriner, Fakultas Kedokteran Hewan, Universitas \\ Airlangga
}

\begin{abstract}
Endometriosis occurs when one of the normal tissues grows ectopically on the organs of the body other than the uterus. One of the mechanisms of infertility associated with endometriosis is a change in immune system function that affects the ovarian follicle which causes an increase in granulosa cells in the ovarian follicle endometriosis patients. The red dragon fruit is one of the plants capable of inhibiting NF-KB secretion of cytotine from endometriosis. This study aims to study the effect of red dragon fruit extract on the ovaries of mice of endometriosis model. 12 samples of female mice divided into 2 groups consisting of positive control group and treatment group used as endometriosis for 14 days, then the next 14 days positive group is given solution $\mathrm{Na}$-CMC 0,5\%, while treatment group given dose $0,25 \mathrm{mg} /$ gram BB. This research type is true experimental by using randomized post test only control experimental group design. The results of this study indicate that there is a significant difference in the number of granulosa cell apoptosis between groups. Provision of extract dragon fruit peel in mice model of endometriosis can decrease the number of granulosa cell apoptosis with significant result $P<0,05$.
\end{abstract}

Keywords : extract of hylocereus polyrhizuspeel, endometriosis, granulose cell apoptotic

\section{PENDAHULUAN}

Infertilitas merupakan tidak terjadinya kehamilan pada pasangan suami istri yang telah berhubungan seksual selama setahun atau lebih secara teratur dan tanpa proteksi. Dilaporkan bahwa wanita infertil memiliki 6 sampai 8 kali lipat kemungkinan memiliki endometriosis dibandingkan wanita subur (ASRM, 2012).

Salah satu mekanisme infertilitas yang diduga terkait dengan endometriosis yaitu adanya peningkatan stress oksidatif, perubahan fungsi sistem imun, perubahan hormonal di dalam zalir folikel dan zalir peritoneum, dan penurunan reseptivitas endometrium(Gupta et al., 2008). Lingkungan mikro peritoneum wanita dengan endometriosis yang mengandung faktor proinflamasi dan ROS memiliki peran penting melalui perubahan komunikasi autokrinparakrin dalam mekanisme perlengketan pelvis, folikulogenesis yang abnormal, berkurangnya kualitas oosit/ embrio, berkurangnya fungsi sperma, dan gangguan implantasi (Hendarto, 2012). Perubahan cairan peritoneum yang menunjukkan peningkatan aktivitas makrofag, sekresinya adalah beberapa sitokin yang menyebabkan terjadinya proses apoptosis patologis. Hal ini terutama ditemukan pada endometriosis berat dengan infertilitas, dimana terjadi proses tersebut pada sel granulosa ovarium dengan ditemukan kadar Interleukin-6 (IL-6) dan IL-8 yang tinggi pada cairan peritoneum. Pertumbuhan lebih lanjut dari sel endometrium akibat menstruasi retrograde kemungkinan juga melibatkan sistem imun penderita endometriosis.

Respon imun pada zalir peritoneum endometriosis berupa peningkatan aktivitas 
makrofrag peritoneum, dilanjutkan terjadinya sekresi berlebihan beberapa sikotin oleh makrofag aktif yaitu IL-1,IL-6,IL-8 dan TNF- $\alpha$ (Bedaiwy, 2002). TNF- $\alpha$ diinisiasi oleh ikatan sitokin tehadap resptor yang menyebabkan aktivasi faktor transkripsi yaitu NK-к $\beta$ (nuclear factor kappa beta) di sel granulosa yang kemudian akan menginduksi gen yang terlibat dalam respon inflamasi dan apoptosis (Kim et al., 2006). jalur ekstrinsik apoptosis dimulai dari perekrutan adapter protein, seperti FADD (Fas associated death domain), membentuk death inducing signaling complex (DISC) untuk mangaktivasi caspase-8dan caspase-10, yang nantinya mengaktifkan caspase-3 sebagai efektor apoptosis (Kalimuthu, 2013).

Ekstrak kulit buah naga merah yang mengandung betalain diketahui mampu menghambat aktivasi IKK NF-KB tidak teraktivasi.pada kultur sel karsinoma mammae MCF-7(Sarasmita dan Laksmiani, 2015).

Pada penelitian ini akan diujikan dua sampel mencit model endometrosis dengan kadar dosis ekstrak kulit naga merah 0,25 $\mathrm{mg} / \mathrm{gram}$ BB mencit selama 14 hari, dosis ekstrak kulit buah naga merah yang digunakan pada penelitian ini mengacu pada penelitian Nugrahaini dan Azizahtentang uji efektifitas antiinflamasi ekstrak kulit buah naga merah pada mencit jantan galur Webster Strain (Nugrahaini and Azizah, 2015).

Untuk itu, penelitian ini dilakukan untuk mengetahui pengaruh pemberian ekstrak kulit buah naga merah terhadap ovarium pada Hewan Coba Mencit Model Endometriosis.

\section{BAHAN DAN METODE}

Jenis penelitian yang digunakan adalah jenis penelitian true experimentaldengan menggunakan randomized post test only control group design.kriteria inklusi pada penelitian ini adalah mencit (Mus musculus) untuk model endometriosis, memiliki ukuran berat badan 20-25 gram, mempunyai bulu yang bersih dan tidak mudah rontok, tidak cacat, tidak ada luka. Sedangkan kriteria eksklusi adalah mencit yang mati pada saat pemberian perlakuan, perilaku mencit berubah saat penelitian (lemas dan tidak lincah).
Bahan yang digunakan dalam penelitian ini meliputi ovarium dari mencit model endometriosis, ekstrak kulit buah naga merahyang buahnya diperoleh dari kebun Agro Wisata Buah Naga Rembangan Kabupaten Jember, siklosporin A (Sandimmun), water fluid injection, biopsi endometrium dari bahan uterus operasi tumor jinak, ethynil estradiol, danbahan pembuatan sediaan histolopatologis. Penelitian ini dilakukan di kandang hewan coba dan laboratorium Patologi Veteriner Fakultas Kedokteran Hewan Universitas Airlangga. Penelitian ini dilakukan selama 2 bulan, mulai bulan Juni sampai Juli 2017

$$
\text { Pembuatan mencit model }
$$

endometriosis meliputi beberapa tahapan, yaitu mencit betina yang sudah dilakukan aklimatisasi selama 1 minggu diberi makan 2 kali sehari dengan pellet ayam, dan diberi minum secara ad libitum, kelompok kontrol positif (K1) dan kelompok perlakuan (K2) diberikan injeksi siklosporin A (Sandimmun) pada hari pertama. Dosis siklosporin A 10 $\mathrm{mg} / \mathrm{kgBB}$ dikonversi pada dosis mencit 1,82 $\mathrm{mg} / \mathrm{mencit}$. Satu ampul siklosporin A setara $50 \mathrm{mg} / \mathrm{ml}$ diencerkan dengan Water Fluid Injection sebanyak $4 \mathrm{ml}$, sehingga siklosporin A diinjeksikan sebanyak $0,2 \mathrm{ml} /$ mencit secara intramuskuler (IM) untuk membuat mencit imunodefisiensi, sementara itu biopsi endometrium diambil dari bahan uterus operasi tumor jinak pada uterus, yang di simpan PBS. Dilakukan washing $2 x$ dengan alat sentrifugal sebesar $2500 \mathrm{rpm}$. Supernatan dibuang, kemudian ditambahkan PBS bersama dengan penicillin $200 \mathrm{IU} / \mathrm{ml}$ dan streptomicin $200 \mathrm{ug} / \mathrm{ml}$. Diambil dengan syringe $3 \mathrm{ml}$ jaringan basah endometrium ini. Setiap mencit akan mendapatkan 0,1 ml. Kemudian disuntikkan secara blind pada kavum peritoneum mencit secara perlahan dalam waktu 60 detik. Penyuntikan dengan disposible $1 \mathrm{ml}$, tetapi menggunakan jarum yang berukuran 16 agar jaringan endometrium dapat masuk. Setelah penyuntikan mencit akan di evaluasi apakah masuk kriteria putus uji atau tidak, selanjutnya dilakukan penyuntikan ethynil estradiolsecara intramuskular pada hari ke-1 dan ke-5. Sediaan ethinyl estradiol dengan dosis $30 \mathrm{ug} / \mathrm{kgbb}$ setelah dikonversi ke mencit menjadi 5,4 ug permencit. Berarti setiap mencit akan mendapatkan 0,1 ml. 
Oleh karena $30 \mathrm{ml}$ mengandung 20000 iu yang setara dengan $2 \mathrm{mg}$ estradiol. Cara penyuntikan pada paha mencit dengan syringe $1 \mathrm{ml}$ dan jarum $1 \mathrm{ml}$, kemudian mencit ditunggu sampai hari ke-14 dengan perawatan pemberian makan dan minum seperti biasa. Setelah hari ke-15, beberapa mencit akan dikorbankan untuk mengetahui terjadi endometriosis, dan kemudian dipapar dengan ekstrak kulit buah naga merah, mencit dipapar ekstrak kulit buah naga merah dosis $0,25 \mathrm{mg} / \mathrm{gram}$ BB selama 14 hari, dan pada hari ke-29, baik mencit yang termasuk kelompok kontrol positif, dan kelompok perlakuan diterminasi untuk diambil bagian ovarium.

Proses ekstraksi kulit buah naga merah dilakukan menggunakan metode maserasi dengan pelarut etanol $96 \%$ dan jumlah apoptosis sel granulosamenggunakan metode imunohistokimia.

Untuk melihat normalitas data, digunakan uji Shapiro-Wilk. Apabila data yang didapatkan berdistribusi normal, akan dilanjutkan dengan uji One Way Anova dan Uji Tukey (HSD).Apabila data yang didapatkan tidak berdistribusi normal, akan dilanjutkan dengan uji Kruskall Wallis, uji Mann Whitney. Penelitian ini menggunakan tingkat kemaknaan sebesar 0,05. Menggunakan spss 16.

\section{HASIL}

Tabel 5.1 mengindikasikan bahwa terdapat perbedaan distribusi jumlah apoptosis sel granulosadari kelompok kontrol positif dan kelompok perlakuan dosis 0,25 $\mathrm{mg} / \mathrm{gram}$ BB. Perbedaan tersebut ditunjukkan oleh adanya penurunan dari jumlah apoptosis sel granulosaseiring pemberian dosis terapi pemberian ekstrak kulit buah naga merah.

\section{Perbandingan Pengaruh Ekstrak Kulit Buah Naga Merah Terhadap Jumlah Apoptosis Sel Granulosa}

Tabel 5.1 Rerata dan simpangan baku jumlah apoptosis sel granulose mencit model endometriosis antara kelompok kontrol dan kelompok yang mendapat terapi ekstrak kulit buah naga merah

\begin{tabular}{lll}
\hline \multicolumn{3}{l}{ RerataJumlah Apoptosis Sel Granulosa } \\
\hline Apoptosis & $\mathbf{K 1}$ & $\mathbf{K 2}$ \\
\cline { 2 - 3 } & $5,88 \pm 2,28$ & $3,28 \pm 0,50$ \\
\hline
\end{tabular}
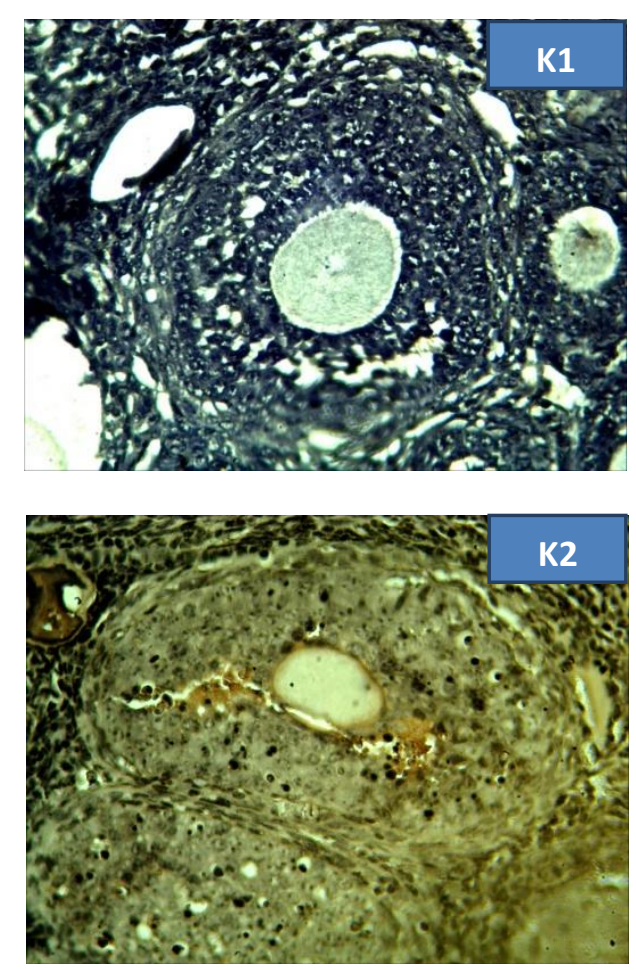

Gambar 5.2Perbedaan ekspresi apoptosis antar kelompok perlakuan. Ekspresi apoptosis tampak sel imunoreaktif yang diekspresikan bewarna cokelat. (Mikroskop Nicon Eclipse e-100, Perbesaran 400x, Optilab Viewer 2.2, Software Pengolah Gambar Image raster 3.0) (Novak, 2007)

\section{PEMBAHASAN}

Apoptosis merupakan proses kematian sel yang terjadi pada sel tunggal secara terencana ditandai dengan gambaran morfologi dan biokimia khas sebagai akibat dari inisiasi oleh stimulasi fisiologi maupun patologi tanpa menimbulkan reaksi radang dan merupakan proses fisiologi untuk perkembangan, pemeliharaan homeostatis dan mempertahankan hospes organisme multiseluler (Zeiss, 2003 ; Daniel, 2004). Pada sistem reproduksi, proses apoptosis berdampak pada fungsi dan perkembangan normal ovarium (Hadi, 2011).

Sel granulosa merupakan sel somatik yang terkait erat dengan folikulogenesis. Fungsi sel tersebut adalah memproduksi 
steroid dan sejumlah faktor pertumbuhan untuk berinteraksi dengan oosit selama perkembangan di ovarium. Apoptosis pada sel granulosa dapat terjadi pada tahapan folikulogenesis (Inoue et al., 2011). TNF- $\alpha$ diinisiasi oleh ikatan sitokin terhadap reseptor yang menyebabkan aktivasi faktor transkripsi yaitu NF-k $\boldsymbol{\beta}$ (nuclear factor kappa beta) di sel granulosa yang kemudian akan menginduksi gen yang terlibat dalam respon inflamasi dan apoptosis(Kim et al., 2006).

Hasil perhitungan rerata jumlah apoptosis sel granulosa menunjukkan bahwa apoptosis sel granulosa terkuat didapatkan pada kelompok kontrol positif. Apoptosis sel granulosa pada kelompok perlakuan lebih rendah daripada kelompok kontrol positif.

$\mathrm{Hal}$ ini sesuai dengan penelitian Oepomo (2003) yang menyatakan bahwa apoptosis sel granulosa pada kelompok endometriosis lebih kuat daripada kelompok kontrol negatif dan kelompok yang mendapat terapi(Oepomo, 2003).

Hasil uji Kruskal Wallis pada indeks apoptosis sel granulosa menunjukkan $p=0,001 \quad(p<0,05)$ dan dapat disimpulkan bahwa pemberian ekstrak kulit buah naga merah dengan dosis $0,25 \mathrm{mg} / \mathrm{gram} \mathrm{BB}$ menyebabkan perbedaan yang bermakna terhadap indeks apoptosis sel granulosa pada kelompok kontrol positif . Hasil uji Man Whitney menunjukkan perbedaan nilai kelompok antara kelompok perlakuan dan kelompok kontrol.

Dalam penelitian kultur sel granulosa yang dilakukan oleh Carlberg et al.,(2000), dilakukan perbandingan beberapa sitokin antara kultur sel granulosa wanita dengan endometriosis dan yang tanpa endometriosis. Didapatkan hasil bahwa terjadi peningkatan produksi dari 4 sitokin yaitu IL-1 $\alpha$, IL-1 $\beta, I L-6$ dan TNF- $\alpha$.namun hanya TNF- $\alpha$. Yang meningkat secara signifikan. Penelitian ini menunjukkan bahwa sel granulosa dapat menjadi sumber produksi dari TNF$\alpha$ (Carlberg, 2000). TNF- $\alpha$ memediasi berbagai respons biologis termasuk peradangan, infeksi dan apoptosis sel. Efek dari TNF- $\alpha$ diinisiasi oleh ikatan sitokin terhadap reseptor, yang menyebabkan aktivasi dari faktor utama transkripsi diantaranya nuclear factor kappa $\beta$ (NF-kB). aktivasi tersebut kemudian menginduksi gen yang terlibat dalam respon inflamasi dan apoptosis(Kim et al., 2006).

Selain itu, Sitokin IL-6 yang disekresikan makrofag ke dalam rongga peritoneum, akan berikatan dengan reseptor IL6R pada sel granulosa ovarium dan menyebabkan aktifnya cascade caspase melalui aktivasi death receptor(Scheller et al., 2011). lewat jalur ekstrinsik atau jalur sitoplasma. Aktivasi death receptor menyebabkan terekrutnya adapter protein FADD (Fas Associated Death Domain) yang kemudian membentuk DISC (Death Inducing Signal Complex) sehingga menyebabkan aktivase dari caspase 8 dan caspase 10. Caspase8 dan 10 akan mengaktifkan caspase 3 sebagai eksekutor apoptosis sel granulosa.

Sel-sel yang diaktifkan oleh sitokin mungkin memproduksi dan mensekresikan sitokin yang sama sebagai sinyal parakrin atau untuk meningkatkan dan menstabilkan sinyal dalam sel yang mensekresi melalui regulasi autokrin. Mekanisme autokrin atau parakrin produksi $T N F-\alpha$ melibatkan beberapa protein, diantaranya $N F-K B$, penghambat $\mathrm{I} \mathrm{KB} \alpha$ dan $\mathrm{A} 20$, penghantar sinyal kinase IKK dan sitokin $T N F-\alpha$ serta reseptornya TNFR1 (Pekalski et al., 2013).

Hasil penelitian ini juga didukung oleh penelitian Ardianta 2015 tentang khasiat kurkumin sebagai antiinflamasi dan penghambatan pada $N F-K B$ sehingga bisa menurunkan apoptosis sel granulosa. Efek antiinflamasi kurkumin dimediasi melalui penekanan terhadap faktor transkripsi $N F_{-K B}$. Kurkumin menghambat aktivasi $N F_{K} B$ dengan mencegah fosforilasi dan degradasi $I K B \alpha$. Kurkumin tidak secara langsung mengganggu aktifitas IKK. Kurkumin memblok degradasi $I K B$ yang diinduksi baik oleh IL- 6 atau TNF- $\alpha$, melalui messenger yang digunakan baik oleh jalur IL-6 atau TNFa. Efek dari kurkumin tersebut mungkin disebabkan oleh gangguan transmisi sinyal protein adapter seperti RIP, TRAF-2, atau TRAF-6, yang memicu aktivasi dari IKK. Kemungkinan lainnya adalah bahwa kurkumin menghambat aktivitas dari messenger yang diinduksi baik oleh $I L-6$ atau $T N F-\alpha$ yang mampu mengaktifkan IKK (Ardianta dkk., 2015). Jobin et al., (1999), menyimpulkan bahwa kurkumin menghambat aktivasi NF-KB yang dimediasi sitokin 
(cytokinemediated NF-kB) dengan memblokir sinyal yang memicu aktivasi IKK (Jobin et al., 1999).

\section{SIMPULAN}

Jumlah apoptosis sel granulosa ovarium pada mencit model endometriosis yang diberi ekstrak kulit buah naga merah (Hylocereus polyrhizus) dengan dosis 0,25 $\mathrm{mg} / \mathrm{gram} \mathrm{BB}$ lebih rendah dibandingkan kelompok kontrol positif.

\section{DAFTAR PUSTAKA}

Ardianta, W.MY., Hendarto, Hendy., Widjiati. 2015. Kurkumin Menurunkan Ekspresi Tumor Necrosis Factor (TNF- $\alpha$ ) Kompleks Oosit-Kumulus Sapi pada Kultur dengan Zalir Peritoneum Penderita Infertil terkait Endometriosis. Majalah Obstetri \& Ginekologi. 23 (23) : 133-139.

ASRM, Practice. Committee. 2012. Endometriosis and infertility: a committee opinion. 98:591-8 Fertility Sterility.

Bedaiwy, K., Dunsmoor-Su, R. and Coutifaris, C. 2002. Effect of endometriosis on in vitro fertilization, Fertility and Sterility 77: 1148-55.

Carlberg, M. 2000.Elevated expression of $T N F-\alpha$ in cultured granulosa cells from women with endometriosis. Hum Reprod 15(6) : 1250-1255.

Daniel, N.N. and Krosmeyer, S.J. 2004. Cell Death : Critical Control Points. Cen. $116: 205-219$.

Gupta, S., Goldberg, J.M., Aziz, N., Goldberg, E., Krajcir, N. and Agarwal, A. 2008. Pathogenic mechanism in endometriosis-associated infertility. Fertility Sterility 90: 247-57.

Hadi, R.S. 2011. Mekanisme Apoptosis pada Regresi Sel Luteal. Majalah Kesehatan PharmaMedika. 3:1.

Hendarto, H. 2012.Pathomechanism of infertilityin endometriosis, in
Endometriosis the basic concept and Current Research Trends. Intech : 343353.

Inoue, Noriyuki, et.,al. 2011. Role of celldeath ligand-receptor system of ganulosa cells in selective follicular atresia in porcine ovary. J Reprod Dev. 57(2) : 169-75.

Jobin, C., Bradham, C.A., Russo, M.P., Juma, B., Narula, A.S., Brenner, D.A. and Sartor, R.B. 1999. Curcumin blocks cytokine-mediated $N F_{-k} B$ activation and proinflammatory gene expression by inhibiting inhibitory factor $I-B$ kinase activity. The Journal of Immunology.163 : 3474-84.

Kim, Y.S., Ahn, Y., Hong, M.H., Joo, S.Y., Kim, K.H., Sohn, I.S., Park, H.W. 2006. Curcumin attenuates Nuclear Factor-k. The Korean Society of circulation. 36: 482-489.

Kalimuthu, S. and Se-Kwon, K. 2013.Cell survival and apoptosis signaling the United States therapeutic target for cancer : Marine bioactive compounds. International Journal of Molecular Sciences 14: 2334-2354.

Novak, M., Madej, J.A., Dziegeil, P. 2007. Intensity of Cox 2 expression inCell of Soft Tissue Fibrosarcomas in Dog As Related to Grade of Tumor malignation. Bull Vet inst Pulawy 51, 275-279. 200

Nugrahaini and Azizah. 2015. Uji Efektifitas Ekstrak Etanol Hylocereus polyrhizus Dengan Metode Geliat Pada Mencit Jantan Galur Swiss Webster. The Muhammadiyah University. Surakarta

Oepomo T.D. 2003. Peran IL-6 serta IL-8 dalam zalir peritoneum penderita infertilitas disertasi endometriosis dalam proses apoptosis sel granulosa ovari yang patologis. Disertasi Program Pascasarjana Universitas Airlangga Surabaya.

Pekalski, J., Zuk, P.J., Kochanczk, M., Junkin, M., Kellog, R., Tay, S. and 
Lipniacki, T. 2013. Spontaneous NF-kB activation by autocrine $T N F-\alpha$ signaling : A computational study, PLOS ONE 8(11) : e78887.

Sarasmita dan Laksmiani. 2015. Test the Sitotoksisitas Ethanol Extract Hylocereus polyrhizus Peel on breast cancer cells in vitro and in silico. The Udayana University.Bali

Scheller, Jurgen., Chalaris, Athena., Arras, Dirk S., and John, Stefan R. 2011. The pro and anti-inflammatory Properties of the Cytokine Interleukin-6, Biochimica et Biophysica Acta. $1813: 878-888$.

Zeiss, J.c. 2003. The Apoptosis-Necrosis Continuun : Insights from Genetically Altered Mice. Vet Pathol, 40: 481-495. 